\title{
Application of Position Auction-Based Merit System in Bantul Regency in 2018
}

\author{
Muhammad Eko Atmojo'), Awang Darumurti1) \& Vindhi Putri Pratiwi ${ }^{2) *}$
}

1) Government Science Study Program, Faculty of Social and Political Sciences, University of Muhammadiyah Yogyakarta, Indonesia

2) Master Program in Government Science, Postgraduate, University of Muhammadiyah

Yogyakarta, Indonesia

Received: 24 November 2020; Reviewed: 09 December 2020; Accepted: 02 July 2021

\begin{abstract}
This article discusses applying a merit system based on job auctions, especially regarding the mechanism for selecting structural officials in the Bantul Regency. They considered that the merit system is a new method for determining structural positions and has become one of the models that local governments have begun to implement in the placement of civil servants, especially echelon II structural officials. The application of this merit system model is one form of implementing Law Number 5 concerning the State Civil Apparatus. Enforced The application of the merit system because a lot of structural position determinations were not based on competence. Still, the structural position determination was based on proximity and political factors. Therefore, with the existence of this Law, it is significant to immediately implement a merit system so that employees who occupy structural positions are competent and professional people. In data analysis, this study was based on the theory of open selection. The method used in this study was qualitative. The data collection techniques used were interviews and documentation. Based on research conducted that the application of the merit system within the Bantul Regency Government was by applicable regulations, as well as in the application of the merit system using several selection methods including administrative selection, assessment centre method/competency test, paper making, track record tracking, percentage of papers and interviews.
\end{abstract}

Keywords: Merit System; Structural Official; Competent and Professional

How to Cite: Atmojo, M.E, \& Darumurti, A., \& Pratiwi, V.P. (2021). Analysis of The Open Selection Process for Structural Officials (Echelon II) in Sleman Regency. JPPUMA: Jurnal Ilmu Pemerintahan dan Sosial Politik UMA (Journal of Governance and Political Social UMA), 9 (2): 129-138.

\begin{tabular}{lr}
\hline *Corresponding author: & ISSN 2549-1660 (Print) \\
E-mail: atmojoeko91@amailcom & ISSN 2550-1305 (Online)
\end{tabular}




\section{INTRODUCTION}

Since the issuance of Law No. 5 of 2014 concerning the State Civil Apparatus as a replacement for Law No. 43 of 1999 concerning the Principles of Employment, the management of the civil service personnel of the State has changed, including regarding the determination of echelon II structural officials. With the existence of this Law, the recruitment of structural officials must be carried out openly or through an auction of positions. It is a form of bureaucratic Reform in the field of personnel. Based on the statement (Zulchaidir, 2011) that one of the efforts made by the government in increasing the capacity of apparatus resources is to carry out "bureaucratic reform" in the field of personnel which is believed to lead to a state of government bureaucracy as a public service expected by the people.

Bureaucratic Reform in the civil service sector is very important, given the direct relationship between the community and the state civil apparatus. Therefore, it is necessary to reform the bureaucracy in the field of personnel to realize quality, transparent, efficient and accountable public services. With the Reform of the bureaucracy through open selection/office auction, it is highly expected that the employees produced and placed can be professional. By their competencies, it aligns with the slogan The Right Man in the Right Place. Thus, this Law is expected to increase the competence and quantity of apparatus resources and change the image of the bureaucracy, which has been stigmatized negatively.

The issue of staffing is one of the problems highlighted by the community, especially in terms of the placement of structural officials. It happens because so far, the filling of structural positions tends to use a closed mechanism (closes career system). With a secure tool, it is very vulnerable to intervention from any party and any group. This process is thick with corruption, collusion, and nepotism practices, which do not reflect the norms in the appointment of structural officials. By the statement to (Wahiyuddin, 2012), the recruitment, selection and transfer, and the career development of civil servants did not pay attention to the principle of competence but are based on political considerations.

Determination based on political considerations and interests will make the bureaucracy increasingly incompetent, and many problems will arise in the bureaucracy. Some issues are caused by the closed promotion system or the appointment of officials who were not based on competence are as follows. First, Lewis et al. (in Sudrajat, 2014) argued that filling structural positions tends to be oriented towards career development of civil servants in stages, which prioritizes seniority in rank and do not prioritize aspects of work performance and competence so that it can have negative implications for structural officials in the form of weak competence, lack of motivation and inefficient bureaucracy. Second, according to (Sudrajat, 2014) the assessment system in structural positions is not fully based on the merit system. The assessment given to Baperjakat is often not based on standardized measuring instruments so that the evaluation becomes subjective and full of intervention. Third, based on Sudrajat (2014), officials who are given the authority to designate structural officials are in political positions, such as governours, regents, and mayors, where these officials are staff supervisors in the regions. The authority is given to staffing supervisors often creates neutrality problems in the appointment of elected structural officials.

The Law on State Civil Apparatus provides a new alternative in determining structural officials through an auction of positions. It is one of the ways made by the government to improve the competence and professionalism of employees. In addition, it is also one way to attract talented personnel resources. According to the Regulation of the Minister for Administrative Reform and Bureaucratic Reform (Menpan-RB) No. 3 of 2014 concerning Procedures for Filling Vacant Structural Positions Openly in Government Agencies, which is also the basis for regulations related to job auctions, explains that the auction of positions or selection and promotion of public classes openly is a system of mechanisms carried out in implementing the appointment of civil servants in an organization. Structural places 
that are carried out based on the principle of professionalism by the competence, work performance and rank levels determined for the position as well as other objective requirements without distinguishing gender, ethnicity, religion, race, or class then this Law is strengthened by Law No.5 of 2014 concerning State Civil Apparatus in article 72 paragraph 2 which reads "Every civil servant who meets the requirements has the same right to be promoted to a higher level of office". It explains that the promotion system must be overt and competitive.

Prasojo (2013) explains that employee recruitment through job auctions is the biggest lever for bureaucratic change, fostering healthy, fair, objective competition, and being free from KKN. This open promotion benefits regional heads, ministers, and LPNK heads since, in this way, they will be able to get candidates for the leadership of restricted work units (SKPD) and the best officials (JPNN, 2013). Position auction is a form of merit system implemented by the government to create a professional bureaucracy and competent employees. With the appointment of the State Civil Apparatus through the merit system, the candidates should be who have competencies according to their fields and professionalism (Yahya \& Mutiarin, 2015). Therefore, implementing this merit system later can reduce the State Civil Apparatus who are not by the competence and expertise in the available field.

Based on research results (Defriadi, 2016), implementing the auction positions still has a lot of problems and bureaucratic pathologies in its application, so bureaucratic Reform should improve the public service system based on the principle of serving becomes negatively stigmatized. Then the auction of positions that will hold will not deny that it will pave the way for nepotism for interest groups who want to occupy structural positions since looking at the history of the DIY Government itself, there is still not enough experience in terms of open auctions for placement of position formations. However, we can say that the DIY government has been using the job auction system for a long time, but the job auction applied is only limited to a unanimous position auction; Agus Supriyanto revealed it as the Head of the Regional Personnel Agency(Natalia, 2015).

Bantul Regency is one of the regencies that implements filling structural officials through open selection/office auction. From 2016, Bantul Regency Government, in filling vacant positions, has implemented an available selection mechanism until now. It was done to reduce fraud and objectivity in determining positions that fill vacant positions. In 2018, Bantul Regency Government carried out an open selection and based on the selection committee's report that there were 43 ASN who registered to participate in the auction of echelon II structural officials, with the position formations, offered as follows: Head of the Education and Training Personnel Agency, Head of the Transportation Service, Head of the Library and Archives Service,(Dahlan, 2016). The filling carried out in the Bantul Regency Government used a job auction system or open selection. It was done to fulfil or obtain Apparatus with integrity, competence, professionalism, high performance, and support the achievement of bureaucratic management within the Bantul Regency Government. Therefore, this researcher focused on applying a merit system based on job auctions within Bantul Regency Government in 2018.

\section{RESEARCH METHOD}

The approach used in the implementation of this research was qualitative. Based on the statement(Moleong, 2012), the notion of qualitative research is research that aims to understand the phenomena of what is experienced by research subjects holistically and using descriptions in the form of words and language, in a particular natural context by utilizing various natural methods. Meanwhile, according to a statement from(Salim, 2006) that qualitative research has the following characteristics: (1) research data is obtained directly from the field, and not from a laboratory or controlled research; (2) data mining is done naturally, making visits to the realistic situations of the subject; and (3) to obtain new meaning in the form of answer categories, the researcher is 
obliged to develop a dialogical situation as a scientific situation. Where this research in Bantul Regency Government. In carrying out the research, data mining was carried out using in-depth interviews. The researchers conducted direct interviews with the BKPP mutation and promotion section, Bantul Regency Open Selection committee, and the open selection participants. The interviewees were the Head of the Division of Mutation and Promotion of BKPP Bantul Regency, civil servants who passed the top 3, ASN who did not qualify for the top 3, and the Position Auction Selection Committee Bantul Regency. After conducting the interview, the researcher processed the data from the discussion and analyzed the data. With the existence of these methods, it is expected that they will further enrich the analytical data presented by the researcher.

\section{RESULTS AND DISCUSSION}

Bureaucratic Reform is one of the national agendas, one of them is about bureaucratic Reform in the field of personnel. One form of bureaucratic Reform in the civil service sector is a state civil apparatus law, where this Law will replace law number 43 of 1999 on the main points of employment. With this Law, it is expected can realize that bureaucratic Reform in the field of personnel. One form of bureaucratic Reform was applying a merit system that translated into an auction of positions or an available selection.

Open selection is a form of bureaucratic Reform that hopes to create competent and professional human resources, especially for echelon II structural officials-considering that this position is strategic and has a very large influence, especially in terms of policymaking. Therefore, people who occupy structural positions in echelon II must have integrity, competence, and work professionally. One way to create professional employees was to conduct an open selection for echelon II structural officials.

Based on the statement from (Nasution, 2015)that the auction of positions aims to select state civil servants who have adequate competence, capacity, and integrity to occupy positions in an organization or government agency so that the programs implemented by the government can run effectively and efficiently. One of the ways to create employees who have competence, capacity and integrity were by bidding for positions or open selection. Because the open selection process was carried out transparently, in several stages and by a neutral party, the employee selection process ran competently. It was reinforced by the opinion (Mokodongan et al., 2019) that this open selection gave the opportunities for all State Civil Apparatuses to compete competently for vacant positions with specifications by the requirements. Therefore, the State Civil Apparatus will be motivated to improve the quality of their performance and have the opportunity to enhance their position later.

Bantul Regency Government conducted an open selection for the first time in 2016. This implementation was a form of the State Civil Apparatus Law and the spirit of bureaucratic Reform promoted by the central government.

With the spirit of bureaucratic Reform, it will positively impact local governments, especially for governments that implement a merit system in the election or determination of echelon II structural positions. Given that this position is one of the strategic positions for local government agencies, it can be seen from the duties and authorities of the head of the service. The form of the merit system implemented by the Bantul Regency Government was one form of bureaucratic Reform in the field of the personnel because, with the auction of this position, expected that people who serve in the Bantul Regency Government, especially structural officials, were people who have high competence, capacity and integrity.

To realize a state civil apparatus with competence, capacity and high integrity, it is significant to have people who can select; one way is to form a selection committee. The selection committee formed by Bantul Regency Government involved various groups consisting of the Bantul Regency Government and agencies outside the government. The composition in creating the auction committee is $60 \%$ from Bantul Regency Government, while $40 \%$ from outside the government. Did it to reduce 
political factors and interest factors in determining the structural positions of echelon II. Therefore, the selection committee from outside the government can be drawn from academia, psychology, etc. The expectation is to get a very objective assessment so that officials who occupy positions are officials who have the competence and high integrity as stated by Sharesbangung, Pioh, \& Waworundeng (2019) that this merit system will also conduct a fair, reasonable assessment without distinction of political background, race, skin colour, religion, gender, or other conditions.

The regulation that was used as the basis for determining the structural position selection committee is Regulation of the Minister for Empowerment of State Apparatus and Bureaucratic Reform (Permenpan RB) Number 13 of 2014 concerning "Procedures for Filling High
Leadership Positions Openly in Government Agencies as the Basis for Implementing Regulations for Open Selection". The regulations that were enforced and used as the basis for determining the selection committee would strengthen the appointment of a selection committee consisting of internal and external. Therefore, political interventions and political interests and groups can be suppressed and have very little opportunity. We were considered that they were the most vulnerable to political intervention and group interests in determining structural positions. Therefore, with the composition of the division of the selection committee, we can expect that the objectives can run the application of the merit system. The following is the distribution of the composition of the selection committee for primary high leadership positions within the Bantul Regency Government.

Table 1. The composition of the JPT Pratama Selection Committee in the Bantul Regency Government

\begin{tabular}{|c|c|c|}
\hline No & Position in the Committee & Position in the Service \\
\hline A. & \multicolumn{2}{|l|}{ SELECTION COMMITTEE } \\
\hline 1. & Chairman concurrently member & Regional Secretary of Bantul Regency \\
\hline 2. & Member & $\begin{array}{l}\text { DIY Secretariat General Administration Assistant } \\
\text { Head of DIY Bappeda } \\
\text { Head of BKD DIY } \\
\text { Head of Kareg } 1 \text { BKN Yogyakarta } \\
\text { Assistant for General Administration of the Regional } \\
\text { Secretariat of the District. Bantul } \\
\text { Plt. Assistant Government Secretariat of the District. } \\
\text { Bantul } \\
\text { Head of the District Inspectorate. Bantul } \\
\text { Academic Elements of UGM Yogyakarta }\end{array}$ \\
\hline B. & \multicolumn{2}{|c|}{ SECRETARIAT SELECTION COMMITTEE } \\
\hline 1 & Chairman & Secretary of BKD Bantul \\
\hline 2 & Vice-Chairman & Head of Head. Transfers and Ranks at BKD Kab. Bantul \\
\hline 3 & Member & Elements of BKD Kab. Bantul \\
\hline
\end{tabular}

The composition of the committee listed in table 1 indicates that the committee's composition involves external elements. Did it realize professionalism in the implementation of open selection; in addition, it was done to create a state civil apparatus with high competence, quality, and integrity. Therefore, in conducting the auction of positions or open selection, the panel can be very free to assess the participants very objectively. It was due to the selection committee that has been formed consisting of internal and external parties; one of them came from academia and several state civil servants who were not from Bantul 
Regency but the provincial and national levels such as BKN.

After the formation of the selection committee, the thing that must do is coordinate with the secretariat of the selection committee, regional heads or regents, and coordinate with the State Civil Apparatus Commission regarding the mechanism for implementing an open selection. If the State Civil Apparatus Commission approves, the committee will announce the available appointment within $t$ Bantul Regency Government. The announcement must be equipped with the requirements and formations needed; it also informed the available selection of high leadership positions outside Bantul Regency. The dissemination of data on the available selection proved that the implementation carried out in Bantul was open to all state civil servants. The people who obtained later were people who had competence, professionalism and high integrity.

All state civil servants can access this position formation through the official website of Bantul Regency Personnel, Education and Training Agency. This information disclosure greatly facilitated all elements of the state civil apparatus in participating in the registration and selection processes. In addition, this transparency greatly reduced the Regional Government in recruiting personnel resources who had high competence, professionalism and integrity. At the implementation stage of this open selection, participants must pass several locations, including conducting administrative selection, assessment centre method/competency test, making papers/papers, tracking track records, presenting documents/reports, and interviews.

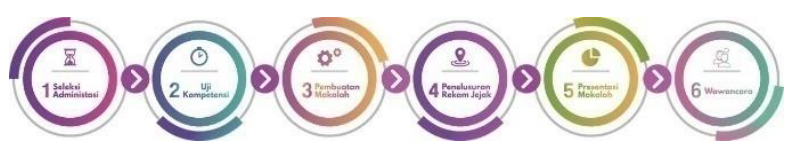

Figure 1. Stages of the Bantul Regency Government's Open Selection Year Source: processed by researchers

Several stages of open selection conducted by the Bantul Regency Government have shown that the government demanded the best employees in providing services to the community. Hence the selection process carried out was quite long and followed applicable regulations. First, the stages used were making announcements of position formation vacancies, which were carried out by disseminating information to all state civil servants through the Bantul Regency Government website and social media. Giving vacancies of job formation can provide opportunities for all state civil servants in Indonesia, especially those who meet the requirements. In addition, the dissemination of this information also gave the Bantul Regency Government great opportunities to get the best employees or follow the objectives of the merit system. Second, by carrying out the administrative selection to recruit employees who met the requirements in implementing an open section in the Bantul Regency Government. This initial screening made the available selection or job auction more competitive. Hence the remaining structural official candidates were the selected candidates. One of the objectives of holding an administrative choice was to apply applicable regulations regarding requirements and classes and ranks to occupy echelon II structural positions. Therefore it was very significant to do due to it being a means of administrative screening.

Third, the assessment centre was one of the competency tests for prospective employees; it was very significant to do because one of the indicators in applying the merit system was to conduct a competency test. The competency test carried out within Bantul Regency Government was the assessment centre, wherein the implementation of this assessment centre several stages of exams must be passed by each candidate for structural officials, including psychological tests and written exams. The purpose of holding this assessment centre/competency test was to find out the behaviour and knowledge of employees so that the accepted employees were employees who have competencies based on their positions. Fourth, At the auction of places in Bantul Regency, not only they did carry out the competency tests, but prospective employees were also asked to 
make papers. The paper made was one of the components or indicators in applying the merit system in Bantul Regency; with the creation of this paper, it was one of the strengthening administrative criteria. Hence, the employees obtained were employees who had a balanced score between the competency test/assessment centre results and writing papers.

Fifth, in addition to carrying out some of the assessments, some assessments were still being carried out, including tracking track records. Track record tracking was a very important thing to do since tracking track records will greatly assist the evaluation committee of the selection committee. They were considering that the panel recommended someone to serve as an official structural candidate, not only based on competency assessment but also other assessment factors. Because the structural position was strategic, the incumbent officer and having a good competence must also have a good track record. Based on Kusumaatmadja's study (2017) in (Daniarsyah, 2017) need for an increase in administrative criteria needs to be done since there was a discrepancy in the assessment phase, writing papers and interviews, as was the case for someone who got good grades in writing an essay after did the assessment, the results were not supportive. Therefore, it needed other reviews, and several evaluations were carried out; one was an assessment of the candidate's track record. This track record can also be used as a component of ethical evaluation, considering that ethics was one of the most important components for a structural official.

Sixth, the next stage was the percentage of papers. They carried out The rate of this paper to determine the extent of prospective structural officials mastering the article. In addition, the portion of writing was also included in the assessment, considering that a structural official was an official who made decisions, therefore the assessment in the procedures and mastery of the material when the percentage was very important to be assessed. Seventh, the last stage was the interview; at this stage, the participants who would be interviewed were only taken three people per formation. Did it base on the assessment results from the selection committee, where took the assessment from the administrative selection to the percentage of papers? At this last stage, the authority to determine candidates for structural officials was the authority of the staffing officer. This last stage was the most vulnerable to political intervention and other interests, considering that the selection committee's decision was a binding and final decision in terms of recommendations, not in determining who was entitled to become an official structural candidate.

Whereas if it was referred to research (Ismail, 2019), according to the conception of scientific discipline, the merit system was a personnel management system that emphasized competency considerations for each candidate appointed, placed, promoted, and retired following the applicable Law. Suppose a merit system based on that statement was applied. In that case, must also find the determination of structural officials on competence, integrity and track record. In addition to determining structural positions, there was no political intervention or intervention of other interests, and there was no familial factor and closeness factor. It was by Law Number 5 of 2014 concerning State Civil Apparatus Article 1 paragraph (22), which states that "The Merit System is a policy and ASN Management based on qualifications, competencies, and performance fairly without distinction of political background, race, colour, religion, origin, gender, marital status, age, or disability.

With the existence of the Law, it is very clear that the determination of structural officials must be based on a merit system, and the decision of structural officials must be based on competence and not based on other factors. If observed the implementation of the merit system in Bantul Regency, it was actually by the applicable rules, where the application of the merit system used several selection methods, starting from the administrative selection to interview selection. However, in applying the merit system, the selection committee only had the authority to recommend three prospective participants, not to determine who would be the candidate for head of the service or 
structural official. The determination of these three candidate names was based on the results of an open selection taken from participants ranked number 1 to three for each formation. The following are the names of participants who passed to the big three stages in implementing the available selection within the Bantul Regency Government.

Table 2. Candidates for Structural Officials for Bantul Regency Government 2016-2019

\begin{tabular}{|c|c|}
\hline \multicolumn{2}{|c|}{ Formation of the Head of the Tourism Office } \\
\hline No & Name \\
\hline 1 & Kwintarto Heru P, S. Sos \\
\hline 2 & Tlau Sakti Santoso, SS, M. Hum \\
\hline 3 & Tri Tujiana, AP, MM \\
\hline \multicolumn{2}{|r|}{ DPRD Secretary Formation } \\
\hline 1 & Praptanugraha, S. Sos, MH \\
\hline 2 & Slamet Santoso, S.IP \\
\hline 3 & Sri Nuryanti, Dra., M.Si \\
\hline \multicolumn{2}{|c|}{ Formation of Head of Health Service } \\
\hline 1 & Agus Budiharja, SKM., M.Kes \\
\hline 2 & Dra. Ninik Istitarini, Apt, MPH \\
\hline 3 & Sidiq Rohadi, SE, MM \\
\hline \multicolumn{2}{|c|}{$\begin{array}{l}\text { Formation of the Head of the Department of } \\
\text { Agriculture, Food, Maritime Affairs and Fisheries }\end{array}$} \\
\hline 1 & Istriyani, S.Pi., MM \\
\hline 2 & Ir. Yunianti Setyorini, M.Sc \\
\hline 3 & Yus Warseno, S. Pi. M.Sc \\
\hline \multicolumn{2}{|c|}{ Formation of the Head of the Trade Service } \\
\hline 1 & Drs. Kurniantara, M.Si \\
\hline 2 & Sahadi Suparjo, SJ., M.Si \\
\hline 3 & Drs. Sukrisna Dwi Susanta, M.Si \\
\hline \multicolumn{2}{|c|}{$\begin{array}{c}\text { Construction of the Head of the Land and Spatial } \\
\text { Planning Service }\end{array}$} \\
\hline 1 & Ari Purwaningsih, SE, M.Si \\
\hline 2 & Ir. Suprianto, M.Si \\
\hline 3 & Ir. Wiyaha, MT \\
\hline
\end{tabular}

\begin{tabular}{|c|c|}
\hline \multicolumn{2}{|c|}{$\begin{array}{l}\text { Formation of the Head of the Office of Population } \\
\text { Control, Family Planning, Community and Village } \\
\text { Empowerment }\end{array}$} \\
\hline 1 & Drs. Wake up Rahina, MM \\
\hline 2 & Dra. Ninik Istitarini, Apt, MPH \\
\hline 3 & Dra. Sri Nuryanti, M.Si \\
\hline \multicolumn{2}{|c|}{$\begin{array}{l}\text { Formation of the Head of the Regional Finance and } \\
\text { Assets Agency }\end{array}$} \\
\hline 1 & Anton Yulianto, AP., M.IP \\
\hline 2 & Dian Mutiara Sri. R, SH., MM \\
\hline 3 & Drs. Trisna Manurung M.Si \\
\hline \multicolumn{2}{|c|}{$\begin{array}{l}\text { Formation of the Head of the Department of } \\
\text { Education, Youth and Sports }\end{array}$} \\
\hline 1 & Drs. Isdarmoko, M.Pd., MMPar \\
\hline 2 & Istiani Nur Hasanah, S.Pd, M.Pd \\
\hline 3 & Tri Kartika Rina, S.Pd., M.Pd \\
\hline
\end{tabular}

Source: processed by researchers from

(https://asn.bantulkabgo.id)
Implementing the merit system carried out by the Bantul Regency Government was quite good by applying several selection methods. The selection committee appointed was by the rules, namely involving internal and external parties. In addition, the determination of the names of candidates for structural officials was also by the procedure by appointing three people for each formation who were ranked first to third. Although had implemented apparatus resource management through the merit system in the Bantul Regency Government well, several things need to be considered, especially in determining structural officials. The determination of structural officials was not the authority of the selection committee but was the authority of the staffing officer or regional head. It needed to be considered since the staffing officers were political officials who had political consequencesassuming that there were still many applications of merit system implementation that were not by reality as stated by (Ismail, 2019) where the process of implementing the merit system still contained many factors of political interest and was contaminated by KKN practices, such as the appointment of candidates that were not by scientific disciplines, the application of professionalism by the interpretation of the intern of power or the placement of employees based on the proximity factor.

The application of the merit system carried out by Bantul Regency Government had been carried out well, it can be supported by a statement from (Irfan, 2017) who stated that one of the weaknesses in his writing about the merit system was there were three things including the high cost, demarcation (restrictions on registrants), and quite a long time. However, in implementing the merit system within Bantul Regency Government, can be refuted Irfan's statement by applying various methods that have been carried out. In addition, the merit system within Bantul Regency Government did not have any boundaries or restrictions; it was indicated by the dissemination of information on job auctions to all state civil servants in DIY and Indonesia. When the 
Bantul Regency government carried out a merit system based on a predetermined schedule, however, several formations were indeed postponed or extended due to several things; one of them was the lack of registrants. Based on this statement, one can conclude that applying a merit system with a job auction model in the Bantul Regency Government had been running by applicable regulations. Although it had been declared good, some weaknesses arose, including determining structural positions; they were still very vulnerable to political intervention and other interest factors. So with this vulnerability, it is significant to have a new model in the appointment of structural officials so that the appointed officials are competent.

\section{CONCLUSION}

Based on the results of the study that has been carried out and the explanations that have been described, the governance of apparatus resources by using a job auction was one form of implementation of law number 5 of 2014. By this Law, all structural position determination models must be based on competence. It can be seen from the method used by Bantul Regency Government in implementing the merit system. There were several methods applied by the Bantul Regency Government in implementing the merit system, including conducting administrative selection, assessment centre/competency test methods, making papers/papers, tracking track records, presentations of papers/papers and interviews. Based on the way used, the application of the merit system within the Bantul Regency Government was by applicable procedures. However, there were still weaknesses in determining structural positions, where the decision of structural classes was the absolute authority of the civil service supervisor or regional head. If seen by officials, staffing supervisors were in political positions, so they were very vulnerable to intervention, or officials' determination was not based on competence but political factors and proximity.

The implementation of a merit system in human resource management was old, but new methods could apply in each region. It was significant to be done within the central and regional governments to get competent and professional employees. In addition, based on the conclusions and explanations that have been presented, one can make some suggestions; one of them is by creating a new model in determining the official structural candidates who had been selected by the selection committee or three candidates who the selection committee had chosen. Hence, there was no intervention; in addition to deciding structural positions, a merit system was applied in which prospective employees' appointment was based on competence and professionalism.

\section{BIBLIOGRAPHY}

Atmojo, M. E., \& Fridayani, H. D. (2019). Analysis of the open selection process for structural officials (echelon ii) in sleman regency. Journal of Governance and Public Policy, 6(2), 170-194.

Dahlan, Y. (2016). Hasil Akhir Seleksi Administrasi Jabatan Pimpinan Tinggi Pratama.

Daniarsyah, D. (2017). Penerapan Sistem Merit Dalam Rekrutmen Terbuka Promosi Jabatan Pimpinan Tinggi ASN. Jurnal Civil Service, 11(2), 39-47.

Defriadi, E. (2016). Rekrutmen Pejabat Struktural Melalui Model Lelang Jabatan Di Pemerintah Provinsi daerah Istimewa Yogyakarta. Universitas Muhammadiyah Yogyakarta.

Horta, H. (2014). Open, merit-based and transparent recruitment. ERAC on Human Resources and Mobility, 1-26.

Irfan, M. (2017). Seleksi Terbuka Jabatan Pimpinan Tinggi Di Lingkungan Instansi Pemerintah. Civil Apparaturus Policy Brief, 5.

Ismail, N. (2019). Merit System Dalam Mewujudkan Transparansi Pembinaan Karier Aparatur Sipil Negara. Jurnal Al'Adl, $X(1)$, 33-42. https://doi.org/10.1017/CB09781107415 324.004

JPNN. (2013). Lelang Jabatan Untungkan PNS dan Kepala Daerah. Retrieved from https://www.jpnn.com/news/lelangjabatan-untungkan-pns-dan-kepaladaerah?page $=3$

Natalia, M.D. (2015). Pemda DIY Pesimistis Dengan Sistem Merit. Retrieved from https://www.solopos.com/pemda-diypesimistis-dengan-sistem-merit-611986 
Meyrina, R. S. A. (2016). Implementasi Peningkatan Kinerja Melalui Merit Sistem Guna Melakanakan Undang-Undang Aparatur Sipil Negara No. 5 Tahun 2014 Di Kementerian Hukum Dan HAM. Jurnal Ilmiah Kebijakan Hukum, 10(2), 175-185. https://doi.org/10.1017/CB09781107415 324.004

Mokodongan, D., Mantiri, M., \& Kumayas, N. (2019). Promosi Jabatan dalam Meningkatkan kinerja Aparatur Sipil Negara (ASN) Di Pemerintah Kota Kotamobagu. Jurnal Jurusan Ilmu Pemerintahan, 3(3), 1-12.

Moleong, L.J. (2012). Metodologi Penelitian Kualitatif (Ed). Bandung: PT. Remaja Rosdakarya.

Nasir. (2019). Implementasi Kebijakan Seleksi Terbuka Dalam Pengisian Jabatan Pimpinan Tinggi Pratama di Lingkup Pemerintahan Kabupaten Toraja Utara. Jurnal Administrasi Publik, 5(2), 154-174.

Nasution, M. S. (2015). Problematika Implementasi Lelang Jabatan Publik.

Nasution, N. (2015). Manajemen Mutu Terpadu. Bogor: Ghalia Indonesia.

Rosmiati, M., Sumaryana, A., \& Buchari, A. (2019). Rekrutmen Terbuka Jabatan Pimpinan Tinggi Pada Badan Kepegawaian Daerah Kota Bandung. Jurnal Administrasi Publik (JAP), 9(2), 228-243.

Sahambangung, O., Pioh, N., \& Waworundeng, W. (2019). Manajemen Sistem Aparatur Sipil Negara (Studi tentang Sistem Merit dalam penempatan jabatan pimpinan tertinggi di lingkungan pemerintahan kabupaten kepulauan sangihe). Eksekutif Jurnal Ilmu Pemerintahan, 3(3), 1-13.

Salim, A. (2006). Teori dan Paradigma Penelitian Sosial. Yogyakarta: Taira Wacana.

Seleksi JPT. (n.d.). Retrieved from Badan Kepegawaian, Pendidikan dan Pelatihan Kabupaten Bantul website: https://asn.bantulkab.go.id/index.php/sel eksi/seleksi-jpt

Sudrajat, T. (2014). Eksistensi Kebijakan Pengisian Jabatan Struktural Dalam Kerangka Pengembangan Sumber Daya Manusia Aparatur Berbasis Merit. Jurnal Kebijakan Dan Manajemen PNS, 8.

Wahiyuddin, L. (2012). Politisasi Pejabat STruktural (Study Kasus Politisasi Pejabat Struktural Eselon II di Sekretariat Daerah Kabupaten Muna Sulawesi Tenggara). Universitas Gajah Mada.

Widyarini, W. (2016). Analisis Seleksi Karyawan Bagian Marketing Di KSPPS BMT El Amanah Kendal Dalam Perspektif Ekonomi Islam (Universitas Islam Negeri Walisongo). https://doi.org/10.1007/s11187-0179901-7

Yahya, M. R., \& Mutiarin, D. (2015). Model Lelang Jabatan Di Pemerintah Daerah Daerah Istimewa Yogyakarta. Journal of Governance and Public Policy, 2(2), 286329.

Zulchaidir. (2011). Proses Rekrutmen Pimpinan Birokrasi Pemerintah Daerah di Kabupaten Sleman dan Kota Parepare. Jurnal Studi Ilmu Pemerintahan, 2(2). 